\title{
The Method of Projects in the Education of Economic Disciplines
}

\author{
Boryana Prashtilova \\ University of Economics \\ College of Tourism \\ Varna, Bulgaria
}

\begin{abstract}
The exploration below is dedicated to the usage of the method of projects in the teaching of economic disciplines. The structure is detailed and all the structures of method, project, methods of teaching and method of projects. The idea of the projects in the didactics is also known with the names of: project method, oriented education, project approach, a project based education or studying. Examples of realized projects on economic disciplines are given, prepared by students and specialists of The University of EconomicsVarna City and students of the College of Tourism to the University of Economics -Varna.
\end{abstract}

Keywords-method; project; method of projects; economic disciplines

\section{INTRODUCTION}

"The method of projects" is a very actual and modern method of teaching and studying. As of pedagogic point of view it can be considered as a strategy for accomplishing the education and as a technology which the students can achieve their knowledge from. The method of project gives opportunities for expanding the appliance of the inter discipline competences within entering the information technologies in the education [1]. More and more the interactive methods in the teaching are used. Projects are prepared within the means of the information technologies which are means for active studying. This method has proved its effectiveness and the improving of the quality of the education process.

\section{The IdEAs of Method, Project AND Method OF TEACHING IN THE PEDAGOGY AND DIDACTICS}

\section{A. The Essence of the Idea Method}

The lexis method is as of Greek origin /methods/ and means a way of exploration and knowledge. In the Bulgarian interpreted dictionary, the language means for method is: a way for theoretical exploration or practical accomplishment, doing of something [2]. In the Bulgarian dictionary if synonyms as synonyms to method are given: way, approach, means [3]. It is accepted that the method is a value of the most suitable means which impact is well known. These means are applied in connection to one another mind achieving or to prove something.

In the book of Pedagogy the methods of teaching are "the means or ways of acting, which the teacher uses as to organize the work at school of the students, arms them with knowledge, skills and habits, checks them and forms a material point of view, developing their mind skills" [4]. I. e. these are the ways that the teacher teaches the students and undergraduates. In the textbook of "Didactics" "for methods we understand all means, and ways for achieving definite aims for solving definite problems and tasks" [5]. Although their universal character, the common didactic methods for each discipline and the economic one as well, have their stipulate. They represent the way of realizing the interconnected activity between the teacher and the student. These methods are used for achieving the aims of each studying, i.e.: an acquisition of knowledge, forming any habits and skills, developing their capacities [6].

The $21^{\text {st. }}$ century is the time of the computer technologies, and of the continuously changing environment for living and studying. By now, the traditional ways of communication between the teacher and the student were only the information methods of tutoring: classical lesson (school story), conversation, lection, consultation. The school story informs, motivates, provokes, emotionally decorates, concentrates the attention. It is obliged to be a Master of Arts and Oratory. The school lection presents the school contention without discussion and activity from the students. The consultation completes the information. It can be initiated both sides. It is used as to correct, to imperfect, store of the knowledge and skills archived. It is executed by a good will. The conversation has a dialogue characted. Both sides must be equal. Making questions must be: exact by content, in a short form, clear and simple for executing, stimulating the thinking of the subjects, successively logical In the nowadays modern schools and universities is unthinkable to communicate without the use of the modern technologies. It is worked by three methods of tutoring: scientific (looking up, experimenting, testing, modeling, measuring, estimating); heuristic modeling (brain-storming, discussion, check-list; debating, associative method); imitative (games, situatede methods, solving task). The observation is to achieve the scientific and exploring skills and it is: spontaneous, descriptive, systematic. The experimenting is as per the achieved knowledge and skills and pointed methods, exploring and acknowledging the reality. The discussing in groups is a discuss, exchanging ideas and opinions, group discussing of problems and tasks. It requires defending and proving of the own opinion, adequate argumentation, critical estimating. The 
brainstorming is finding the most suitable decision of a current task or problem. It is aimed to stimulate the free generating of ideas, the non- standard thinking is approved, irony and mocking are not allowed. With the "check - list" the group art is stimulated, i.e. using different forms of mental activity-non-standard and adaptiveness.

R. Stoyanova describes the different definitions of the concept "method of tutoring", met in the methodic literature:

- The method is a system of ways of teaching [7] [8] [9] [10] [11];

- The method is a system of the ways and means and /or the forms of teaching [12] [13];

- The method is a system of principles of education [14] [15] [16];

- The method is a system of principles of teaching, based on definite non-methodic systems [17];

- The method is a technique for manual instruction of the actions of the students [18];

- The method is a model of realization of the basic components of the teaching process [19];

- The method is a common imagine of the scheme of interaction between the teacher and the student [20], [21];

- The method is a direction in the education [22] [23];

- The method is a conception of teaching [24] [25] [26];

- The method is a way, method for achieving the aim [27] [28] [29] [30] [31].

\section{B. The Essence of the Concept "Project"}

The name of project comes out of the Latin word "projectus" which means "coming", "progressive". The formal definition of project is unique and limited in the time enterprise. Under unique it is understanding that the result of the project is a new product or service and limited in the time means that there are definite beginning and end.

D. Mitova suggests a common definition of a "project":

- "Plan, chart, modul, sketch, purpose, drawing" (Bulgarian interpreted dictionary);

- "A complex of documents for creating some product a preliminary text of a document which to be discussed, revised and accepted, solving a definite problem or a problem within appreciating an ability through a row of agreed activities" (Bulgarian interpreted dictionary);

- "Something, thrown away in advance, planed or already started of something we have planned "[32];

- "Innovative tasks, which require a way of proceeding, which is not under the influence of the linear organization and the routine methods" (Definition according to Kraus /Vesterman/);
- "A temporary enterprise undertaken with the aim of creating of a unique product to service " [33];

- "A unique and limited in the time beginning, and the result of the project is a: new product or service with a predetermined beginning and end" (Definition, given as of the Institute -PMI-the international organization of professionals in the management of projects);

- An intention which is basely characterized through the unique of the conditions of the in their community, for example - an aim, termed, financial, personal or other distinctions, abstracting from other opinions and intentions, specific for the project organization [34].

As per definition, the project is a complex of definite actions, documents, preliminary texts; thinking of creating a real object and subject, for creating a different by its origin a theoretical product. This is always an art action.

In the temporary conditions of teaching, the question for developing the art thinking of the students arises a obligative condition for its realizing in the practices is the eliminating of the dominative role of the tutor in the process of achieving knowledge and experience. That is why the entering in the pedagogic process of elements of the exploring activity of the students and graduates gives to the teacher ability not only to teach but to help to the teaching one to study and to point its knowledge activity.

One of the most spread out kinds of explored labor within the students and graduates in the process of learning is the: Method of "Method of Projects" - subject and particularities.

1) How the "method of projects" has appeared: The concept "Method of Projects" in the education is met with the names of: a project method, a project-oriented education, a project approach, a project-based education or studying etc. It is looked over as alternative of the class-studying system. The modern project (a course project, a presentation) of the student or the graduate is a didactic means for activating the knowledge activity, developing the creativity and in the same way of definite personal qualities. Depending on the specific national and educational environment, the concept of "Method of the projects" is met in different variants (Italy, Canada, Latin America), a project of based educational technologies (Russia, USA, Australia); method of projects (Europe - Russia, Germany, France, etc.).

A meaning of the modern teaching is the proved in the Pedagogy understanding that the "Method of Projects" has begun in the beginning go 20th century in the USA. It is also called the method of problems and is connected to the ideas of the humanistic ally flood in the Philosophy and education, developed by the American philosopher and pedagogy John Dui and his student William Kilpatrick. As per John Doumani man can be pushed to a knowledge only when it is put in a situation of the unknown regarding something. As the problem to be solved, a definite strategy should be taken, which includes the estimating of the problem. Preparing a hypothesis, experimenting and going to the conclusion [35]. 
In the pedagogic points of view of Dui the idea for the "problem situation" is in the base as of the only way for achieving new knowledge. According to Dui, the students must be active observers, not passive, and to make experiments and to analyze. It is all about a question of "teaching through a mediator's activity". This way they will connect their theoretical knowledge with the reality of life.

A base principal which this method of projects is based in accomplishing the interrupted connection of the studying material with the life experience of the students in their common knowledge and art activity, when solving a problem (project) [36].

The method of projects attracts the attention of the Russian pedagogies in the beginning of the 20th century. The ideas of the project education begin in Russia with practices alongside with the developing of the American ones. Under the management of the Russian pedagogue S.T. Shtatski during 1905, a small group of coordinators is organized, which tries to use actively the project methods in the tutor's activity. Later, within the Soviet authority these ideas became to enter in school, but they were not taught over and in consequence. During 1931 the method of projects is judged and as of then up to the beginning of the 90 years in Russia there are no serious actions made this method in the school practice to be restored [37]. In Europe, during the 20th and 30th years of the 20th century, the project method begins to be used in countries like Germany, Italy, Great Britain, Norway, Switzerland and others.

- The Dutch pedagogue M. Knoll makes thorough period of the developing and use of the project method in the education, making a clear distinction chronologically between the five periods as it follows: First tries for work at a project in the architect schools in Europe (1590-1765) [38];

- Affirming the project as method of teaching and its meaning in America (1765-1880);

- Developing of projects in the sphere of the labor education and the mass schools (1880-1915);

- Pre-definition of the project method and its bringing back to Europe from America (1915-1965);

- Discovering again the idea of the project and the third wave of the world spread out (as of 1965 - up to date) [39].

2) Basic components of the "method of projects": According to some modern scientists (V. Gurova; V. Valkanova, V. Bozholova, G. Dermendzhieva), the basic components of the project method are:

- The school content to have (clear aims, to responds to the definite in advance criteria and standards and to be tied to the making of the project and its product);

- Multimedia (use of different technical means for the aims of the planning, realizing and presentation of the project);
- Instructions and project documentation (for an ease of the students in the realization of the project and realization of feedback and estimating); Cooperation between all the participating students (direct and indirect) in the project;

- Connection with the real life (through the communication, accomplished with people from the practices and the real life);

- A time frame (as the time being for the project is bigger, the more activities will be executed by the students). An innovative treatment to the estimating (variative, periodic and final); documenting, selfestimating and others [40].

These components are totally valid for the project method in the economic disciplines. The graduates in the College of Tourism to the University of Economics Varna and the University of Economics Varna prepare their projects as per the studied by them disciplines for the current course and speciality. For example: $1^{\text {st }}$ course "Management of hotels and restaurants" speciality - College of Tourism, project per themes "Introduction in the Tourism", "Restaurant Management", "Technology of the culinary production", "Commodity Science", "Technology of the Service in a Restaurant", "Business Informational Technologies", Russian; $3^{\text {rd }}$ course - "Management of the Leisure Time" - College of Tourism; projects on "Marketing in the Tourism", "Marketing and Management of the events", "Marketing communications", "Management of the human resources"; $4^{\text {th }}$ course -"Management" - University of Economics, project on "Planning and forecasting", "Business analysis"; post graduates at the University of Economics Varna, "Pedagogy", projects in "Pedagogic Psychology", "Pedagogic Ethics", "Pedagogy", "Civil Education".

3) Classification of the projects: According to D. Mitova the following classification of the projects can be made:

- Practical oriented - the results of the concrete activity are expressed in a concrete, and useful and practical oriented product ;

- Exploring the problems - with a character of a scientific exploration (with a character of a scientific problem, an object, a subject; aims and tasks; methods of exploration; making and proving of hypothesis, analysis of the results, conclusions);

- Informational - they require gathering, treatment, analysis, systematization aggregation and presenting the information on some kind of problem, an object, an appearance and presenting the information on some of the problems, an object, an appearance, scientific facts and others through different information sources in the Internet. These projects are often integrated with the exploration ones, and the end product can be a scientific article, an abstract, a report or presentation; 
- Creative - with the use of untraditional methods and achieving of the creative product (with elements of subjective news) according to the individual creative thinking and interests of the students and graduates;

- Role-playing - the students or graduates reproduce practical situations, imitate social or working relations, undertake roles from the professional activity of the elder [41].

\section{EXAMPLES OF PROJECTS UNDER ECONOMIC} DISCIPLINES BY ECONOMISTS AND GRADUATES UNDER THE PEDAGOGY PROGRAM AT THE UNIVERSITY OF ECONOMICS VARNA AND STUDENTS AT THE COLLEGE OF TOURISM AT THE UNIVERSITY OF ECONOMICS - VARNA

As examples we will mention a small part of the projects realized by student economists and graduates under the program "Pedagogy" of the University of Economics - Varna and by students at the College of Tourism at the Economic University of Varna in 2017/2018 academic year:

- "Hisarya - Successful Tourist Destination", 1st place at the "Scientific Student Session 2018" at the College of Tourism at the University of Economics Varna, 1st course student at the College of Tourism;

- "Interactive Museum in Gabrovo as a contemporary emotional and cognitive space", took 2nd place in the "Scientific Student Session 2018 at the College of Tourism at the University of Economics - Varna", students 3rd course at the College of Tourism;

- "Tolerance of the students in Tourism", 3rd place in "Scientific Student Session 2018 of the College of Tourism at the University of Economics - Varna", student 2 nd at the College of Tourism.

- "Walk in the Holy Mountain", 3rd place in "Scientific Student Session 2018г. of the College of Tourism at the University of Economics - Varna", student 1st course at the College of Tourism;

- "Essence of Tourism in the Municipality of Tryavna" - "Scientific Student Session 2018 of the College of Tourism at the University of Economics - Varna", student 1st course at the College of Tourism;

- "Nature of Tourism in the Municipality of Tryavna" Participation in "Scientific Student Session 2018г. of the College of Tourism at the University of Economics - Varna", student 1st course at the College of Tourism at the University of Economics Varna";

- "Unique Collective Tourism Program - Seven Great Rila Lakes" - Participation in "Scientific Student Session 2018г. of the College of Tourism at the University of Economics - Varna", student 1st course at the College of Tourism at the University of Economics - Varna";

- "Unique program on pedestrian tourism - The Seven Rila Lakes", presentation on the lines of the game - participation in the International Forum on the theme "Russian language and languages of the people of Russia in the context of the development of the unified socio-cultural space of the Russian Federation", was held in Moscow on 19.04.2018, students 1st course in the College of Tourism;

- "Essence, Role and Importance of Tourism in Tryavna and the Region", course project "Introduction to Tourism", student 1st course at the College of Tourism;

- "Evaluation of the fulfillment of the requirements of the Ordinance for categorization in restaurant "RANCHERO STEHHOUSE" - Varna, course project in "Restaurant", student 1st course at the College of Tourism;

- "Study of the structure of the yoghurt assortment, offered by Bulgarian producers and traders in the online shop SHOP 24", course project in "Stoichenie", student 1st course at the College of Tourism;

- "Fast male cuisine", presentation on "Technology of culinary production", student 1 st course at the College of Tourism;

- "Study of the structure of the assortment of highalcohol unsweetened beverages offered on the Bulgarian market", course project "Stoichenie", student 1st course at the College of Tourism;

- "Assessment of the fulfillment of the requirements of the Ordinance for Categorization in the tavern "Odayata"- Varna, course project in "Restaurant", student 1 st course at the College of Tourism;

- "Aesthetic layout of dishes", presentation on "Technology of culinary production", student 1st course at the College of Tourism;

- "Good Practices in Tourism in Orpheus Hotel Devin", presentation on "Introduction to Tourism", student 1 st course at the College of Tourism;

- "Good Practices in Tourism in the Village of Krapets", Presentation on "Introduction to Tourism", student 1 st course at the College of Tourism;

- "Good Practices in tourism at Grand Flamingo Hotel - Albena", presentation on "Introduction to Tourism", student 1 st course at College of Tourism;

- "Trends in Tourism Development in Albena Resort", Course on "Introduction to Tourism", student 1st course at the College of Tourism;

- "Marketing analysis of a leisure and tourism object", "Marketing in Tourism" course, student 3rd course at the College of Tourism;

- "Sports event for students from universities and colleges in Varna - with cause and purpose of entertainment", course project "Marketing and Event 
Management", student 3rd course at the College of Tourism;

- "Recruitment techniques, assessment and socialization of human resources", Human Resource Management course, student 3rd course at the College of Tourism;

- "Via Ferrata Ecopath", project "Marketing", student 3rd course at the College of Tourism;

- "Development of a map of consumer behavior", presentation on "Marketing", student 3rd course at the College of Tourism;

- "Marketing analysis of an object in the field of leisure and tourism", presentation on "Marketing", student 3rd course at the College of Tourism;

- "Advertising-essence, meaning, channels and means", presentation on "Marketing", student 3rd course at the College of Tourism;

- "Product Value", presentation on "Marketing", student 3rd course at the College of Tourism;

- "Presentation of different types of events and discussion of their results, characteristics and role", presentation on "Marketing", student 3rd course at the College of Tourism;

- "Evaluation of a project for the creation of AquaparkRavadinovo", project "Planning and Forecasting", student 4th course at the University of Economics;

- "Lukoil-Bourgas AD Financial Profit" project, "Business Analyzes" project, student 4th course at the University of Economics;

- "Psychology of the personality of the teacher and the pedagogical activity", a pedagogical psychology course project, a postgraduate student at the Pedagogical University;

- "Ethical Basis of Interaction in Pedagogical Process: Teacher-Teachers, Teacher-Pedagogical Team, Teacher-Parent", a course project in "Pedagogic Ethics", a post graduate at the University of Economics in Pedagogy;

- "Principles and methods of education", a course project in "Pedagogy", a post graduate at the University of Economics in Pedagogy;

- "The State - the main political institution", a course project in "Civil Education", a post graduate at the University of Economics in Pedagogy.

\section{CONCLUSION}

According to R. Stoyanova, "the existing variety of training methods enables teachers to take creative initiative in the search for and selection of those that are most effective and conform to the conditions of the particular learning process, respectively with the objectives and tasks of the training, the real possibilities and age characteristics of the learners, the knowledge, skills and habits acquired by them, the nature of the study material, the existing material base of the learning process and, last but not least, the personal and professional qualities of the teacher himself " [42]

The variety of training methods applied at the Bulgarian universities, as well as at the Varna University of Economics and the College of Tourism at the University of Varna, in particular the use of the "Method of Projects", help to enrich the learning process.

The teaching of economic disciplines through the Project Method makes the presentation of the learning material more diverse and contributes to the activation of learners' participation in the learning process. Teachers are increasingly presenting their lectures in the form of presentations. They strive to use modern technologies to be modern, interesting, to conquer the audience, to increase student motivation, etc. On the other hand, students learn not only to develop their rational but also creative thinking and knowledge.

In the classrooms, teachers and students often exchange places, i.e. the trainer is not a side observer, and the trainees are the main actors. The teacher directs, controls and counsels. Students are left to choose the themes of their projects themselves, the ways of developing and presenting them. They learn how to make decisions themselves and take responsibility for them. There are no limitations in the creative layout and presentation of their projects.

They learn to speak to a large audience without worrying They can work both individually and in groups. This improves their ability to work in a team. They learn how to navigate and use different sources of information (printed publications and electronic sources). The implementation of the projects helps to acquire knowledge and skills besides the respective economic discipline, but also for working with Office programs (WORD, PowerPoint, Excel, Access). I believe that through the "Project Method" the quality of teaching is enhanced. The curiosity of students to acquire new theoretical knowledge and practical skills is stimulated. Even if they have not done very well with project development, the teachers give them a delicate assignment.

\section{REFERENCES}

[1] N. Koleva, Method of Projects in the Context of the Quality of Education, Management and Education, volume IX (4), 2013, pp. 216-223.

[2] L. Andreychin, L. Georgiev, St. Iliev, N. Kostov, Iv. Lekov, St Stoykov, Ts. Todorov, Sofia: Publishing House "Science and Art", 2002.

[3] M. Dimitrova, A. Spassova, Dictionary of the Modern Bulgarian Literary Language, Sofia: Institute for Bulgarian Language, Publishing House of the Bulgarian Academy of Sciences, 1980.

[4] G. Khrusanov, V. Danailov, Iv. Ivanov, Pedagogy, Sofia: "Science and Art" Publishing House, 1965.

[5] M. Andreev, Didactics, Sofia: Publishing "Narodna Prosveta", 1983.

[6] D. Mitova, Project Oriented Technology Training - Theory and Methodology, Blagoevgrad: University Press “N. Rilski”, 2011, p. 36.

[7] I.V. Rahmanov, Story and history on the methid of teaching new modern west European languages, Moscow, 1947. 
[8] A. L. Bim, Questions about the methods of teaching in different languages/International languages in school, 1974, № 2.

[9] Mehtod of teaching Russian language as a foreign one. Hrystomathy / Creator A.N. Shtukin, Voronezh, 1998.

[10] Method of teaching Russian language as a foreign in the junior school/ G.I. Dergacheva, O.S. Kuzina, N.M. Malashenko, V.M. Nechaeva, A.V. Frolkina, Moscow, 1989.

[11] O.D. Mitrofanova, V.G. Kostomarov, M.N. Viatutnev, E.U. Sosenko, E.M. Stepanova, Method of teaching the Russian language as a foreign, Moscow, 1990.

[12] St. Kabasanov, M. Ivanov, L. Stavreva, R. Rusinov, Methods of teaching Bulgarian language in the high school, Sofia, 1965.

[13] St. Kabasanov, Methods of teaching the Bulgarian language for 4th to 7th grade of the Technical Highschool, Sofia, 1979.

[14] V.B. Beliaev, International story for teaching of psychology, Moscow, 1965.

[15] M.V. Liyahovitski, Some basic methods of teaching foreigners/Foreign languages in school, 1973, no. I.

[16] E.U. Passov, Bases of the communication of methods of teaching for foreign languages, Moscow, 1989.

[17] A. Radkova, The method in the methodics // The language and literature: Mehtodic paradigmus and educational policies / Created by M. Gerdzhikova, A. Damianova, A. Petrov and others, Sofia, 2005.

[18] T.A. Ilinna, Pedagogy, Moscow, 1969

[19] M.V. Liyahovitski, Some basic methods of teaching foreigners

[20] A.Y. Lerner, Didactic base methods of teaching, Moscow, 1976.

[21] Y. Lerner, Didactic methods of teaching, Moscow, 1981.

[22] T. H. Kapitonova, A. N. Shtukin, Modern methods of teaching Russian language for foreigners, Moscow, 1979.

[23] Method of teaching Russian language as a foreign in the junior school/ G.I. Dergacheva, O.S. Kuzina, N.M. Malashenko, V.M. Nechaeva, A.V. Frolkina, Moscow, 1989

[24] U. V. Vannikov, T. S. Kudriavtseva, The problem with teaching Russian language for foreigners and ideas of structural and methodic factures Russian language for foreigners, 1980, No. 4.

[25] B. M. Esandjyan, Scientific base and method of preparing the teachers tutoring the Russian language for foreigners, Moscow, 1984.

[26] F. Ilieva, H. Helmih, German-Bulgarian dictionary of the concepts in the foreign methodics, Sofia, 1984.

[27] G. Hrusanov, D. Denev, I. Ivanov, S. Chernev, M. Andreev, Pedagogy, Sofia, 1976.

[28] Method of teaching Russian language as a foreign in the junior school/ G.I. Dergacheva, O.S. Kuzina, N.M. Malashenko, V.M. Nechaeva, A.V. Frolkina, Moscow, 1989

[29] R. Yoveva, Methodics of the literal education, Shumen, 2000.

[30] Pedagogy, University textbook under the management of Plamen Radev. Auto: Pl. Radev; P. Lazarov; D. Pavlov; At. Popov; At. Bliantova; K. Kandeva; Zl. Kasandrova; R. Ivanova; O. Koychev; P. Katsharov; A. Aleksandrova, 2001.

[31] R. Stoyanova, The concepts of "training method", "technology of training" and "information and communication technologies" in the modern method pf tutoring of foreign language // XVII-XVIII Derzhavin Readings: Modern and Historical Problems of Bulgarian Studies and Slavonic Studies: Materials of the XLI International Philological Conference March 26-31, 2012, St. Petersburg. Materials of the XLII International Philological Conference 11-17 March 2013, St. Petersburg. Publishing house of St. Petersburg University, 2013, pp. 67-84.

[32] Electronic Publication: http://www.brockhaus-enzyklopaedie.de

[33] Electronic Publication: Project management - Part 1: Principles and guidelines for the management of projects, Third (present) edition, September 2010 , p. https://www.slideshare.net/minhnhutchautran/bs-06079-1201059707699

[34] D. Mitova, Project Oriented Technology Training - Theory and Methodology, Blagoevgrad: University Press "N. Rilski”, 2011, p. 9.
[35] Electronic Publication: http://webstage.bg/filosofiya-ipsihologiya/3864-obrazovanieto-ne-e-podgotovka-za-zhivota-to-esamiyat-zhivot-dzhon-dyui.html

[36] D. Mitova, Project Oriented Technology Training - Theory and Methodology, Blagoevgrad: University Press 'N. Rilski”, 2011, p. 16.

[37] Electronic Publication: Project based education in Information Technologies 7th. grade, https://www.studsell.com/view/134388/20000/

[38] Knoll., M. The Project Method / It's Vocational Education Originand Alternal Development, University of Bayreuth, Spring, 1997, Vol. 34 Number 3. P. 36-74.

[39] D. Mitova, p. 10

[40] V. Gurova, V. Bozhilova, V. Valkanova, G. Dermendzhieva, Interactivity in the educational process or fisherman, fish and fishery, Sofia: Europress Agency, 2006

[41] D. Mitova, p. 63.

[42] Stoyanova, R. The concepts of "training method", "technology of training" and "information and communication technologies" in the modern method pf tutoring of foreign language // XVII-XVIII Derzhavin Readings: Modern and Historical Problems of Bulgarian Studies and Slavonic Studies: Materials of the XLI International Philological Conference March 26-31, 2012, St. Petersburg. Materials of the XLII International Philological Conference 11-17 March 2013 , St. Petersburg. Publishing house of St. Petersburg University, 2013, p $67-84$ 